\title{
A Preliminary Analysis of the Wear Pathways of Sliding Contacts on Temporomandibular Joint Total Joint Replacement Prostheses
}

\author{
Henrique Pinto-Borges ${ }^{1}$, Oscar Carvalho ${ }^{2}\left(\mathbb{D}\right.$, Bruno Henriques ${ }^{2,3}$, Filipe Silva ${ }^{2}$, António Ramos ${ }^{4}(\mathbb{D}$ \\ and Júlio C. M. Souza $1,2, * \mathbb{D}$ \\ 1 Department of Dental Sciences, University Institute of Health Sciences (IUCS), CESPU, \\ 4585-116 Gandra PRD, Portugal; julio.souza@iucs.cespu.pt \\ 2 Center for Microelectromechanical Systems (CMEMS-UMinho), University of Minho, \\ 48058-058 Guimarães, Portugal; oscar.carvalho@dem.uminho.pt (O.C.); \\ brunohenriques@dem.uminho.pt (B.H.); fsamuel@dem.uminho.pt (F.S.) \\ 3 Ceramic and Composite Materials Research Group (CERMAT), Federal University of Santa Catarina (UFSC), \\ Campus Trindade, Florianópolis 88040-900, Brazil \\ 4 TEMA, Department of Industrial Engineering, University of Aveiro, 3810-193 Aveiro, Portugal; a.ramos@ua.pt \\ * Correspondence: jsouza@dem.uminho.pt
}

check for updates

Citation: Pinto-Borges, H.; Carvalho, O.; Henriques, B.; Silva, F.; Ramos, A.; Souza, J.C.M. A Preliminary Analysis of the Wear Pathways of Sliding Contacts on Temporomandibular Joint Total Joint Replacement Prostheses. Metals 2021, 11, 685. https://doi.org/10.3390/ met11050685

Received: 11 February 2021

Accepted: 13 April 2021

Published: 22 April 2021

Publisher's Note: MDPI stays neutral with regard to jurisdictional claims in published maps and institutional affiliations.

Copyright: (c) 2021 by the authors. Licensee MDPI, Basel, Switzerland. This article is an open access article distributed under the terms and conditions of the Creative Commons Attribution (CC BY) license (https:// creativecommons.org/licenses/by/ $4.0 /)$.
Abstract: In the last years, several materials and design have been assessed in an attempt to improve the mechanical performance of temporomandibular joint total joint replacement (TMJ TJR) prostheses. However, the wear of the TMJ TJR condyle to the polymer-based fossa component during loading and sliding movements. That promotes the release of debris and risks of toxicity to the surrounding tissues. The purpose of this study was to perform a narrative literature review on the wear of TMJ TJR sliding contacts and potential toxicity of metallic debris to the patients. Previous studies reported a significant deterioration of the sliding contact surfaces of TMJ TJR prostheses. Material loss as a result of wear can cause a TMJ TJR condyle/fossa mismatch and the modification of the contact pressure and chewing loading. As a further consequence of wear, metal particles are released to the surrounding tissues with a high risk of local tissue and systemic toxicity through the bloodstream. The presence of particles induces the stimulation of inflammatory reactions depending on the concentration and size of debris. Thus, CoCr-based condyle release metallic ions and sub-micron particles that can be engulfed by macrophages or internalized by other tissue cells. The wear and material loss of TMJ TJR could be decreased by design optimization and novel materials with low friction and contact pressure. That consequently decrease the amount of metallic ions and particles to the surrounding tissues, preventing peri-prosthetic inflammatory reactions.

Keywords: debris; temporomandibular joint total joint replacement; wear; toxicity

\section{Introduction}

Among the currently available biomedical materials, the long-term success rates of titanium-based dental implants have supported the use of titanium and its alloys to manufacture implants and prosthetic devices [1,2]. The human synovial temporomandibular joint (TMJ) is formed by the mandible condyle, fibrous articular disc, and temporal bone fossa. Essential human functions such as chewing, speaking, airway support, and swallowing are supported by the function and shape of the TMJ. Indeed, the TMJ complex is often under cyclic load, more than any other joint in the body throughout life. These physiologic actions occur thanks to the rotation movement of the condyle over the articular disc and the translation of the disc-condyle complex along the articular prominence [3,4]. Around 25\% world population is affected by some type of temporomandibular joint disorder (TMD) such as muscular pain, opening mouth limitations, migraines, and bruxism, although 
surgical procedures are recommended in only $2-5 \%$ of TMD cases $[3,5,6]$. TMD disorders is prevalent in females within a 1:3 ratio with males, ranging from 20 up to 40 years old. In the USA, approximately 1 million people per year are diagnosed with a TMD, although only around $3 \mathrm{k}$ patients need surgical procedures [7-10]. Common causes for surgical procedures with TMJ total joint replacement (TJR) are related to severe trauma or end-stage joint diseases such as ankylosis, degenerative diseases (i.e., osteoarthritis), and tumors [3,5,6,11]. End-stage joint diseases are characterized by the degradation of cartilage and bone tissue that cushions and smooths the joint movement followed by pain, swelling, stiffness resulting in a loss of mobility and function $[3,5,6,11,12]$.

The long-term performance of TMJ TJR prostheses is similar to that of the most used orthopedic implant or prostheses (i.e., hip, knee TJR) ranging between 15 and 20 years, that is not enough for most of the elderly population $[7,13]$. Nevertheless, young patients can also need TMJ reconstruction and the number of TMJ TJR prostheses have arisen in recent years $[6,7,14-16]$. A previous study reported data on an increasing demand for the use of TMJ TJR devices until the year 2030 in the USA regarding the treatment of terminal TMD [6]. The main factors that limit the long term performance of the alloplastic prostheses are related to mechanical instability due to progressive bone resorption, material degradation, and adverse reaction to metallic debris [16-20].

Two categories of total TMJ TJR prosthesis have been studied: standard prostheses, where the surgeon needs to adapt the patient's anatomical features; and custom-made prostheses for each clinical situation (Figure 1) [9,21-23]. On the manufacturing of prostheses, titanium alloys are used to promote osseointegration in the mandible ramus and articular fossa. Cobalt-Chromium ( $\mathrm{CoCr}$ )-based alloys are used to replace the condyle that is placed in contact with a prosthetic articular fossa composed of a polymeric material such as ultra-high-molecular-weight polyethylene (UHMWPE). That CoCr-UHMWPE pair results in low friction that allows a free movement during physiologic movement of the patient $[4,9]$. The preparation and surgical treatment with TMJ TJR prostheses must guarantee a functional occlusion to decrease stresses and the wear of the contacting materials. The placement of the prosthesis requires a reference for the correct maxilla-mandibular positioning of the components to gather stability during and after surgical intervention. The prediction of a stable mandibular position in patients without occlusal stability or edentulism becomes a hard challenge and therefore that can compromise the primary stability of the TMJ TJR implants. In these cases, the use of myorelaxant occlusal device is indicated to maintain a proper vertical occlusal dimension during and after surgery [24-26]. The postsurgical period involves a physiotherapeutic treatment (i.e., passive, active, cryotherapy, ultrasound, transcutaneous electrical nerve stimulation) to reduce musculoskeletal pain and therefore promoting patient comfort [26-28].
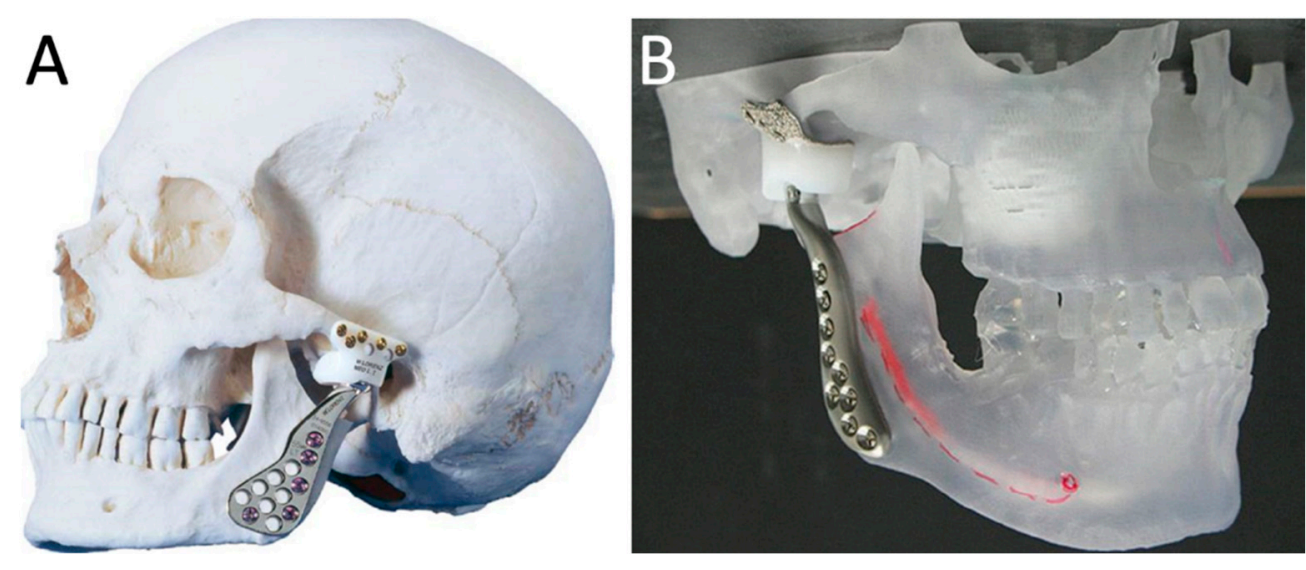

Figure 1. Images of (A) a standard and (B) a custom-made temporomandibular joint total joint replacement (TMJ TJR) prosthesis. 
Considering the articular disc is absent, there is only a small contact area between the condylar component and the temporal component [29]. Regardless of the material, the loading is located at a small contact area that results in higher stresses and wear rate of materials leading to the release of debris to the surrounding tissues $[7,9,30,31]$. The levels of wear pathways depend on factors such as the roughness, materials, design, loading, and contact area of the two surfaces $[7,13,31]$. The materials used to produce these devices have acceptable biocompatibility, although there is a significant percentage of the population $(\sim 10 \%)$ that reveals allergy to the CoCrMo alloy $[16,30,32,33]$. The release of debris such wear particles (i.e., CoCrMo and UHMWPE) and metallic ions do affect the cells of the surrounding tissues, including osteogenic cells, fibroblasts, mesenchymal cells and cells of the immune system (lymphocytes, macrophages). As a result, the inflammatory reaction takes place including various events, such as cytokine production, cell apoptosis, and activation of osteoclasts $[18,20,30,34]$.

Taking into account the degradation of TMJ TJR prostheses, the present work aims to carry out a narrative review on the wear of TMJ TJR sliding contacts and toxic consequences related to the release of metallic debris from wear and corrosion processes.

\section{Standard and Custom-Made TMJ TJR Prostheses}

The first functional system for standard TMJ TJR prostheses was created in the $60 \mathrm{~s}$ by Christensen $[10,35,36]$. Currently, three TMJR TJR devices were approved by FDA: stock (off-the-shelf) and custom patient-specific (Zimmer Biomet, Warsaw, IN, USA); custom (patient-fitted) prosthesis (TMJ Concepts, Ventura, CA, USA); Christensen stock prosthesis (TMJ implants Nexus CMF, Salt Lake City, UT, USA) [4]. Biomet/Lorenz (Zimmer Biomet, Germany) is one of the most used standard system with FDA approval $[10,35,36]$. In a previous clinical and radiological study of 33 patients, the VAS scale for Biomet stock prostheses between 2010 and 2016 improved for pain, diet, incisal opening, and quality of life before and after surgery of the patients [37]. Clinical studies published between 2005 and 2012 suggested a success rate of standard TMJ TJR ranging from 84 up to $91 \%$ [38]. Total stock or standard TMJ TJR includes a mandibular component available in three different sizes $(55,50$, and $45 \mathrm{~mm})$ as well as a prosthetic articular fossa in different sizes (wide, medium, small), as shown in Figure 1 [21,22,32,39]. These types of prostheses have a CoCrMo alloy (ASTM type F799 or F1537) condyle coupled to the mandible ramus component composed of titanium grade $\mathrm{V}$ to promote the osseointegration process [37,40,41]. On Zimmer Biomet TMJ TJR, the fossa component consists of an ultra-high molecular density polyethylene (UHMWPE) component, without metallic support [4,41-43]. Both components are fixed using $2.0 \mathrm{~mm}$ self-tapping screws for the articular fossa and $2.7 \mathrm{~mm}$ for the mandibular component $[40-42,44]$. Considering the manufacturing materials, the clinical performance of TMJ TJR prostheses is similar to that of hip or knee TJR prostheses and therefore TMJ TJR prostheses need periodic recall evaluation or grafting surgeries in some cases, increasing the complexity of surgical interventions and the costs of treatments $[7,45]$.

TMJ TJR surgical procedure issues involve the positioning and the use alloplastic cements or bone graft materials $[5,22]$. On standard components, the articular fossa and the mandibular ramus have to be changed, or the prosthesis itself needs to be fitted to increase primary stability. In this way, there is a high probably of mechanical instability such as micro-movements between different components due to the lack of positioning or fitting $[22,46]$. Although the prosthetic articular fossa can be stabilized without the use of bone graft materials, anatomic features (i.e., deep articular fossa) can limit the fitting of the TMJ TJR prostheses [22,37]. Then, the use of bone graft materials can be an alternative when there is lack of fitting in the surgical site. Thus, that procedure is a safe method to achieve the required levels of mechanical stability and that avoids bone resorption of the joint eminence, which causes micro-movements leading to implant failure [47]. In the treatment of very asymmetric patients and with high mandibular angles, the placement of standard TMJ TJR prostheses becomes more challenging due to the limited shape and design [48]. 
Since the surface of the condylar component is relatively flat, an optimal fitting in the surgical bed becomes a limitation. Thus, the frontal inclination of the ramus and mandibular condyle must be meticulously evaluated. In a frontal view, the portion of the condyle head of the standard TMJ TJR prosthesis can be positioned laterally whether the lower margin of the ramus component in the area of the mandibular angle is located medially to the glenoid fossa [49]. An opposite situation may occur if the lower margin of the condyle components of the standard TMJ TJR prosthesis in the area of the mandibular angle is located laterally to the glenoid fossa. Those issues can be solved by controlling the insertion depth of the fixation screws [49]. The standard TMJ TJR system usually involves a two-step protocol. On the first surgery, the ankylosed bone is removed to provide a suitable bone space for placing a spacer component. Within the second surgery, the spacer component is removed and the selected TMJ TJR prosthesis is placed $[11,21,47,48]$. The benefits of standard TMJ TJR involve low cost and immediate availability $[21,49,50]$. Several authors report an increase in the number of standard TMJ TJR with satisfactory results of mouth opening within a period of 3 or 8 years [32,40,41,51].

Custom-made TMJ TJR are designed and engineered according to the patient's anatomic features, requiring little or no changes on the surgical procedure [23,42] (Figure 1B). Custommade TMJ TJR prostheses have a better performance when compared to standard TMJ TJR prostheses due to several factors. One noteworthy benefit of custom-made TMJ TJR is related to the fitting leading to a decrease in micro-movements of components and consequent high mechanical stability. The screws' positioning in the prosthetic articular fossa and in the mandible ramus also promotes a shorter surgical time once osteoplasty is not required [50]. The main disadvantages of custom-made TMJ TJR prostheses are the costs, the manufacturing time, and the bureaucratic process for government authorization in some countries $[22,39,49,52,53]$. Considering the customized TMJ TJR components are well-fitted to the anatomic features of the patient, the temporomandibular recovery is enhanced, decreasing risks of failures, postsurgical issues, and discomfort to the patient $[43,54]$. Thus, customized manufacturing by using CAD-CAM or 3-D printing offers clear benefits over standard TMJ TJR $[4,54,55]$.

On the custom-made TMJ TJR, the articular fossa component can consist of a commercially pure titanium (cp Ti) mesh or rough framework adhered to UHMWPE. Cp Ti mesh or rough framework allow the integration of bone and soft tissues that promote the mechanical stability of the TMJ TJR prosthesis. The condyle component is composed of CoCrMo while the ramus is composed of titanium alloy (e.g., Ti6Al4V). Both components are anchored with Ti6Al4V screws $[4,42,43]$. The length of the screws can be previously designed, avoiding constant probing during surgery and then preventing the placement of longer screws that can injure the medial pterygoid muscle [55]. In the case of the articular fossa component, the sharp tips of the screws can reach the temporal muscle if they penetrate beyond the available functional space [55]. The component of the mandibular fossa is screw-retained to the lateral edge of the glenoid cavity while the mandibular component is screw-retained to the ramus [11]. The screw retaining must provide a maximum stability according to the manufacturer's guidelines [56]. However, the access to the uppermost holes, close to the condyle, may not be possible without resorting to tissue retraction maneuvers, that increases the risk of tissue damage. In that case, at least 5 screws (50\% to 100\%) are recommended to avoid failures [56]. An alternative screw positioning approach can involve the use of a hole just below the condylar head that allows the placement of the screw from medial to lateral or anterior to posterior, depending on the surgeon's preference [57]. This allows a vertical suspension suture to maintain an upright position until the scar tissue is remodeled to support the jaw. A PDS 2/0 suture is used, attached around one of the screws holding the mandibular fossa component [57]. The high mechanical stability of TMJ TJR prostheses reduces wear on contacting surfaces, decreasing the release of debris to the surrounding tissues and consequent adverse inflammatory reactions, that also occur on knee and hip prostheses $[7,45,58]$. Although the life expectancy of custom-made TMJ TJR prostheses is undefined, Wolford et al. [11] published a 20-year follow-up study of 56 patients (52 women and 4 men) with an average age at $38.6 \pm 10.0$ years who received 
custom-made TMJ TJR prostheses. According to the findings, there was an improvement in the function scores of incisal opening measurement, pain, and diet. None of the prostheses failed, which indicates a high long-term performance of those devices [11]. There are numerous published articles that validate the successful use of custom-made TMJ TJR prostheses with an indication of significant improvement in the incisal opening, mandibular function, and in pain levels. Approximately $87 \%$ of patients reported improvement in their quality of life [13,38,56,59].

\section{Degradation of TMJ TJR Components}

The degradation of TMJ TJR prostheses depends on a series of factors such as primary stability level, surface conditions, loading, wear resistance, and properties of the materials. Improvements of the mechanical properties of materials in contact with bone is still an industrial challenge, that has limitations considering the current materials. For instance, the elastic modulus of bone tissues ranges from 4 up to $30 \mathrm{GPa}$, depending on the type and anatomic region of bone, while the elastic modulus of the titanium alloys used in the screws varies from 130 up to $150 \mathrm{GPa}$ [4,9]. The mismatch in elastic modulus leads to abrupt loading transference and concentration at prosthetic interfaces. The transference of loading through the TMJ TJR prosthesis can cause bone resorption or fibrosis if the TMJ TJR is mechanically instable [60]. In fact, a high magnitude of loading at the base of the skull has been recorded ranging from 60 up to $150 \mathrm{~N}$ in the anterior region and around $270 \mathrm{~N}$ in the posterior region $[9,13]$. In patients with temporomandibular disorders (TMD) involving bruxism, the load magnitude from the maxillo-mandibular relationship can be higher when compared with a physiologic condition. In such TMD cases including TMJ TJR, the resultant contact pressure (load vs. cross-sectioned area) between condyle and articular fossa leads to high risks of fracture and wear of the related TMJ TJR materials $[7,45]$. Several studies have shown findings from computational simulations associated or not with experimental tests on TMJ TJR to predict the stress magnitude on their components [9,38,61-63]. Regarding the positioning of the TMJ TJR condyle, high stresses were recorded when the condyle was placed at the outer and posterior regions of the mandibular ramus $[61,63]$. However, stresses were lower on custom-made TMJ TJR condyles when compared to standard TMJ TJR ones [64]. Considering the fixation screws positioning, the stresses were higher on the condyle-ramus component border fixation screws than on the central fixation screws. The decrease in stresses occurred when the number of fixation screws increased [65]. In fact, the decrease in stresses through the materials can improve the mechanical stability of the TMJ TJR and the wear behavior of the contacting surfaces under normal and frictional loading. The stability of the prosthesis also depends on the fitting of the components, which can reveal limitations in patients with extensive bone defects or who have undergone previous surgery $[23,60,66]$.

CoCr-based alloys have adequate mechanical properties to withstand the complex loading from the occlusal contacts during the chewing process $[4,9,61,66]$. Among the mechanical properties, the wear and fatigue resistance against polymeric surfaces has been reported in the literature $[4,7,13,29,66]$. The prosthetic articular fossa component composed of UHMWPE also has considerable resistance to fatigue and promotes a low friction against metallic materials such as CoCr- or titanium-based alloys $[4,29,31,42]$. Nevertheless, the wear of TMJ TJR contact surfaces has also been reported in recent studies [7,31,45]. For instance, surface damage to retrieved TMJ TJR condyle surfaces was detected by optical light interferometry and scanning electron microscopy [7]. The morphological aspect of the TMJ TJR condyle composed of CoCrMo were representative of pitting corrosion, bi-directional scratches, plastic deformation, and corrosion products (Figure 2C,D). The scratches and plastic deformation could also occur during the TMJ TJR manufacturing and surgical placement [7]. Electrochemical tests (OCP and EIS) of the retrieved TMJ TJR condyle surfaces corroborate the Raman spectroscopy on the corrosion kinetics of the surfaces [7]. The previous findings revealed that the brunt of the functional loading is a key factor on the TMJ devices as reported on orthopedic total joint replacement 
(TJR) [7]. The consequences of the wear of surfaces consist in the degradation and release of metallic debris to the surrounding environment. Another previous study reported the release of metallic ions from TMJ TJR components in a serum medium that indicated the oxidation and corrosion of metallic surfaces [30].
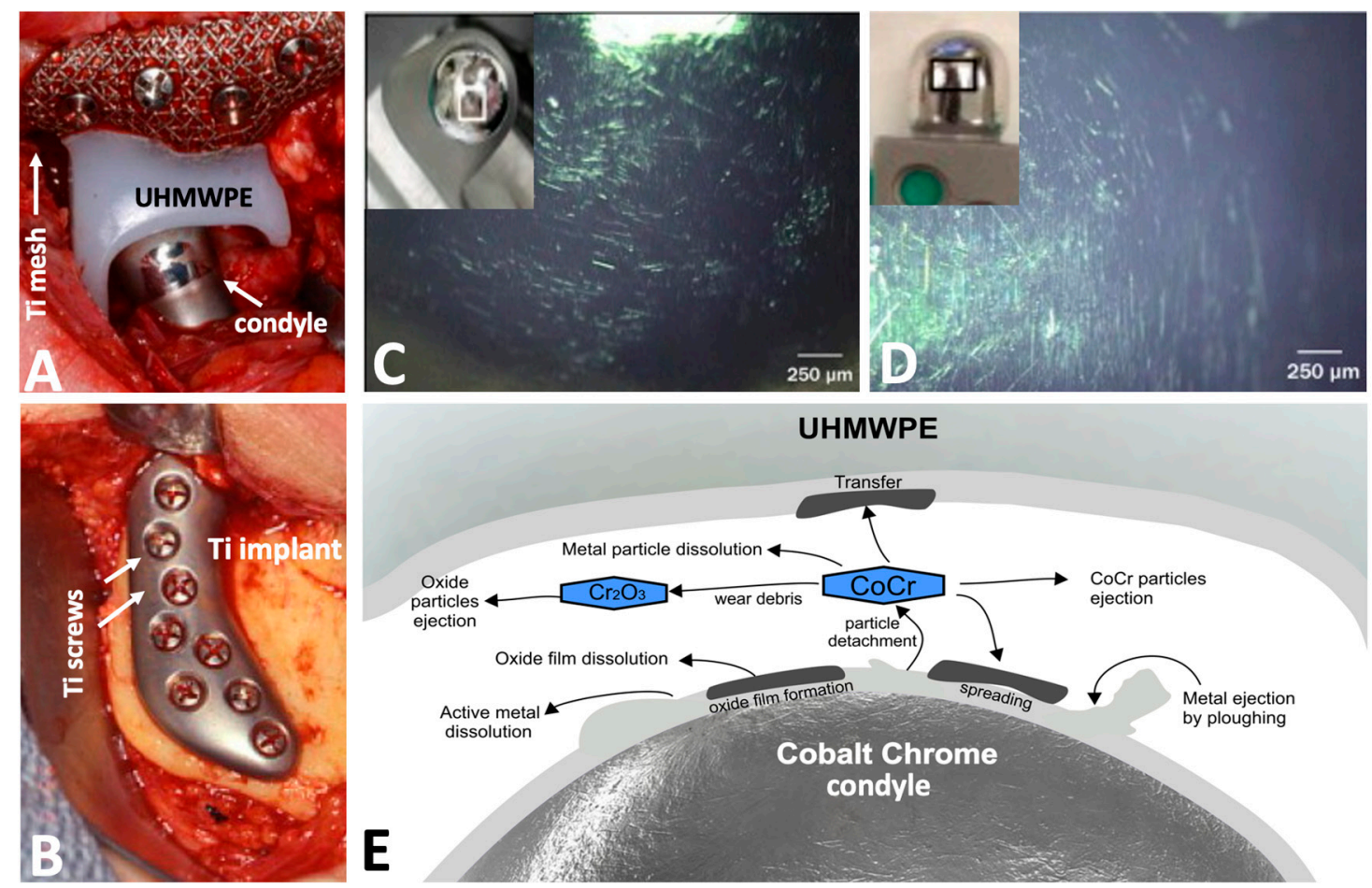

Figure 2. Images of the TMJ TJR (A) condyle and (B) ramus implant. Microscopic images $(\times 93.5)$ revealing abrasive scratches on the (C) custom-made and (D) standard condyle surfaces. Reprinted/adapted with permission from [7] (Elsevier 2016). (E) Schematics of the wear pathways on CoCr-based condyle vs. ultra-high-molecular-weight polyethylene (UHMWPE) fossa surfaces.

During the sliding of the TMJ TJR condyle onto the synthetic polymeric fossa, a twobody abrasion takes place on the tribological pair (i.e., CoCr versus UHMWPE) [4,42]. Abrasion wear can occur on both surfaces since they are rubbing away from each other by direct contact with their asperities (micro- and nano-scale peaks) under oscillatory and complex loading $[7,45,67,68]$. The abrasion results in the plastic deformation of the contacting surfaces depending on the normal (axial) loading magnitude and roughness (micro/nano-scale peaks' dimensions) of the components $[7,45,67,68]$. In a wear track, the plastic deformation occurs by ploughing with the fracture (micro-cracks) regions and ejection of materials from both contacting surfaces [69-71]. In fact, fatigue also occurs within the wear pathways since there is a rupture of intermolecular bonds followed by a subsurface damage caused by the movement of surface molecules under cyclic loads [71,72]. As a result, there is a release of metallic and polymeric debris to the peri-prosthetic region [7,31]. Then, abrasive particles move along the surfaces in tribological contacts, scratching away the antagonist surface. If the prosthetic contacts act as a closed tribological system, the material loss will be higher when compared to the material loss in open environment where the abrasive particles move away from the tribological contact zone [71,72]. Wear adhesion is another related pathway once wear particles can also become attached like platelet shapes to surfaces forming tribo-layers under friction. However, fracture of the microwelds resulting from adhesive wear can occur, leading to an increase in the wear rate [71]. Thus, hard debris such as CoCr-based particles act as third bodies in the wear pathways, leading to an increased wear rate of the surfaces as illustrated in Figure 2. Surface wear 
and consequent loss of contacting volume is one of the main causes of degradation of TMJ TJR prostheses $[7,45]$.

The surrounding liquid medium also influence the wear behavior of the contacting surfaces. In the presence of proteins, the liquid medium acts as a lubricant, decreasing the friction and consequent wear rate [73]. The thin oxide film (passive oxide film) composed of $\mathrm{Cr}_{\mathrm{x}} \mathrm{O}_{\mathrm{y}}$ onto $\mathrm{CoCr}$-based surfaces or $\mathrm{Ti}_{\mathrm{x}} \mathrm{O}_{\mathrm{y}}$ on titanium-based surfaces also remain stable $[68,70,71,74]$. However, thin oxide films can be destroyed under increased friction and sliding wear. On the other hand, an acidic medium can induce the corrosion of metallic surfaces and speed up the degradation of materials by a synergistic effect of wear and corrosion pathways, known as tribocorrosion $[68,70,71,74]$. In acidic medium, the thin oxide film formed onto the $\mathrm{CoCr}$ - and titanium-based surfaces chemically interact with the $\mathrm{H}^{+}$and other ions (i.e., $\mathrm{Cl}^{-}$) leading to a partial dissolution (active oxide film) [72,74-76]. As a result, the release of metallic ions and debris such as nano-particles exposes a fresh $\mathrm{CoCr}$ - or titanium-based surface that promptly reacts with the environment corresponding to an anodic partial current [72,74-76]. It should be emphasized that the bare metal has a high chemical reactivity to the medium once the thin protective oxide film was removed. Thus, a galvanic coupling is established during the wear process in the electrolyte, since the bare (worn area) may act as an anode or a cathode, while the peripheric area, composed of a passive layer (unworn area), acts as a cathode or an anode [70-72]. The current flowing between anodic and cathodic areas represents an increased corrosion rate of the metallic material. Previous studies have reported the tribocorrosion of $\mathrm{CoCr}$ - and titanium-base surfaces in different medium such as saline, artificial saliva, phosphate buffered solution (PBS), biofilms, and protein-rich serum [31,70,72,73,75,77].

Designing contact surfaces is one way to reduce wear of TMJ TJR materials. A recent approach has proposed the modification of the condyle surfaces with a deposition of titanium nitride (TiN) or diamond-like carbon (DLC) layer, that can decrease friction and wear of the condyle component. The same approach has been utilized in the case of the condylar structure of hip TJR prostheses [16,42]. In fact, veneering metallic surfaces with DLC or TiN could provide a protective barrier against corrosion and wear, increasing the long-term performance of the contacting TMJ TJR surfaces. Also, the high-strength ceramic condyles could be an alternative to avoid the corrosion issue [78]. However, the microstructure integrity (i.e., absence of defects) and low roughness of the modified surfaces should be controlled to promote such low friction effect. Defects such pores or rough coating surface are quite common considering the manufacturing processes. The detachment of coatings can also occur during normal and tangential loading during cyclic sliding and normal loading. As a consequence, third bodies increase the wear of the bearing surfaces.

UHMWPE is the major polymeric material for bearing surfaces of TMJ TJR, due to its biocompatibility, low friction coefficient, resilience, strength, and corrosion resistance properties [42,79]. Despite these properties, degradation by wear on UHMWPE is unavoidable, which requires the consideration of alternative polymers. Many UHMWPE structures are sterilized by gamma irradiation at room environment. This has subsequently been shown to cause oxidative degradation of the polymer both in vitro and in vivo leading to an increased wear rate and release of polymeric debris $[79,80]$. Some studies have reported a lower friction when a highly cross-linked polyethylene (XLPE) counter-body was used instead of UHMWPE against CoCr-based surfaces [78,81]. Contrarily to hip and knee prostheses, only a few studies are available that describe the tribocorrosion behavior and biological response of novel advancements in TMJ TJR prostheses [4,19,45,82]. Further studies are required to validate the effect of different pairs of bearing surfaces considering variation of loading, geometrical models, coatings, roughness, and novel materials.

\section{Adverse Biological Effects of Debris Released from TMJ TJR}

Previous studies have reported that the failures of the TMJ TJR prostheses can be related to a synergistic effect among friction, wear, and corrosion resulting in the release of 
metallic ions as well as metallic and polymeric debris $[7,29,45]$. The levels of metallic debris and ions have been reported after TMJR TJR $[30,83]$. The particles (ceramic, metals, and polymers) and ions can accumulate around the peri-prosthetic tissues, promoting adverse local tissue reactions such as necrosis, osteolysis, and pseudo-tumors [30]. The presence of ions and debris into the tissues activates endothelial cells at the peri-prosthetic region causing the expression of molecules such as P-selectin, ICAM-1, CAM and CD44. In this way, immune cells (granulocytes, macrophages, monocytes, and lymphocytes) are stimulated by those molecules towards the tissue interfaces $[30,84]$. Then, the immune cells induce the discharge of a variety of prostaglandins, degradative enzymes, growth factors, reactive oxygen species (ROS), and pro-inflammatory cytokines including TNF-a, interleukins (IL-1a, IL-1b, IL-6 and IL-8), as illustrated in Figure 3. Several studies report that primary cytokines stimulate the release of other mediators. The consequent inflammatory cascade results in the recruitment of other types of cells and the formation of a peri-implant granuloma [84-86]. The fusion of macrophages results in multinucleated-giant cells and osteoclasts that adsorb onto the metallic particles' surfaces [86,87].

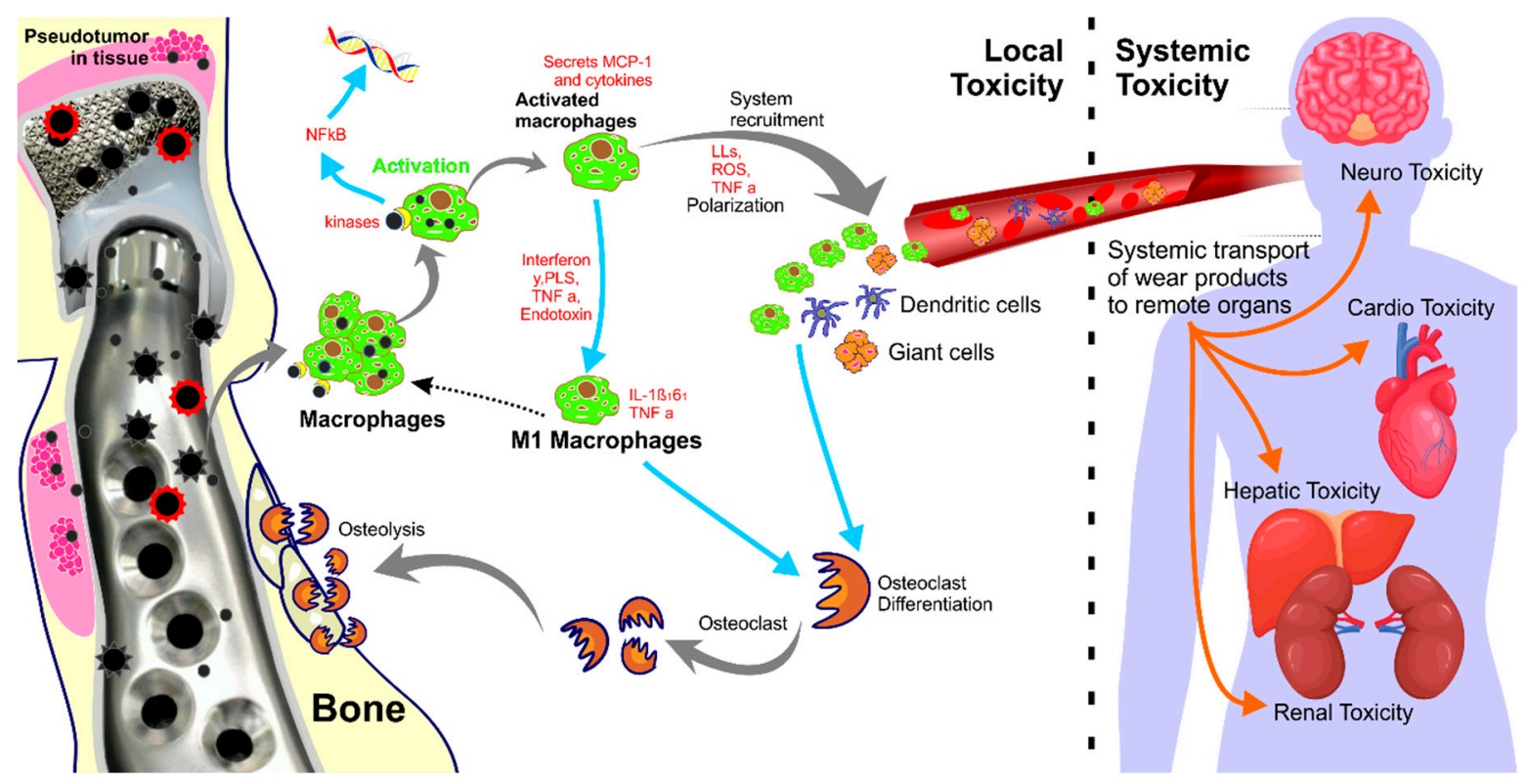

Figure 3. Schematics of the toxic effects of metallics debris released from the degradation of TMJ TJR prostheses.

On degradation, UHMWPE particles can be released like granules, splinters, or flakes instead of the needle-like shape that has noticed for Ti and CoCr-based materials. Immediately on implant placement, synthetic materials spontaneously adsorb a layer of host proteins that mediate the interaction with immune cells (e.g., macrophages, neutrophils). For instance, macrophages interact with wear particles through the layer of adsorbed serum proteins, including type I collagen, aggrecan proteoglycans, immunoglobulin, fibronectin and albumin (Figure 3) [80,88]. It is well-known that UHMWPE particles in the $0.1-1.0 \mu \mathrm{m}$ size range have been shown to be more biologically reactive than larger particles. Submicron-scale particles have been involved in inflammatory reactions of late aseptic loosening of total joint replacements [89]. Regarding the differences in size, submicronand nano-scale UHMWPE particles are engulfed by macrophages that attempt to degrade the polymeric particles, although without success. The macrophages become activated and release prostaglandins, cytokines (TNF- $\alpha$, IL-6, IL-1, IL-8), metalloproteinases and lysosomal enzymes [88,89].

Metallic ions and submicron- and nano-scale particles released from surface degradation are chemically active and can interact at the level of cellular organelles with potential risks of mutagenic reactions $[86,90]$. The biological response of cells depends on the chemical composition, size, and amount of the particles and ions [85,86]. The main CoCr-based 
alloys used to manufacture the condyle have approximately $68 \% \mathrm{Co}, 28 \% \mathrm{Cr}$, and $7 \%$ Mo, while titanium alloys (Ti grade V) have around $89 \% \mathrm{Ti}, 6 \% \mathrm{Al}$, and $4 \% \mathrm{~V}$. Metallic particles can be found from micro- (below 1-50 $\mu \mathrm{m}$ ) up to nano-scale (1-100 nm) size after tribocorrosion of a CoCr- or titanium-based condyle against a UHMWPE [86,87,91,92]. CoCr micro- and nano-scale particles and $\mathrm{Co}^{2+}, \mathrm{Cr}^{3+}, \mathrm{Cr}^{6+}$ ions are the main degradation products from CoCr-based alloys [7,92]. CoCr nano-particles and $\mathrm{Cr}^{3+}$ ions can trespass the cell membrane by diffusion or endocytosis, generating reactive oxygen and nitrogen species and disturbing the respiratory function of the cells. Submicron- $(0.1-0.99 \mu \mathrm{m})$ and nano-scale particles are internalized by the cells via pinocytosis and phagocytosis processes of macrophages [93]. Also, the nano-scale debris and ions can reach the cell DNA inducing mutagenic reactions, as illustrated in Figure 3. The saturation of metallic debris has a negative consequence in the antioxidant mechanism of the cells causing cell wall damage and metabolism disorders $[18,86]$. Studies have reported apoptosis and inflammatory responses in macrophages and pneumocytes when in contact with $\mathrm{Co}^{2+}$ and $\mathrm{Cr}^{3+}$ [86]. Additionally, $\mathrm{Co}^{2+}$ can influence iron metabolism by interaction with apo-transferrin that might affect the physiologic hematopoietic tissue metabolism. A previous study reported toxic concentrations for $\mathrm{Co}^{2+}$ at 8-10 ppm and 250-500 ppm for $\mathrm{Cr}^{3+}$ [94].

Furthermore, systemic toxicity cold take place when the debris and ions get into the bloodstream and reach lymph nodes, liver, spleen, and bone marrow [30,86]. A relationship between wear debris accumulation and upregulation of metalloprotein I/II has been reported that can result in the alteration of xenobiotic metabolism by liver [95]. Erytrocytes containing metal circulate throughout the body tissues and amplify the risks of genotoxicity and immunological effects $[86,87]$. The metallic debris can trespass different cells and tissues and can also be transferred among organs. An in vivo study reported metal accumulation in liver and kidney tissues after intramuscular placement of a CoCrMo implant for 9 months [96]. Such finding suggested that metal particles and ions are released from CoCr-based implants even under non-functional conditions. In fact, TMJR TJR components (condyle, screws, fossa mesh, and ramus) are sources of release of metallic debris and ions. Regarding the titanium-based ramus and screws, many manufacturers use Ti6Al4V alloys due their high strength and capability of osseointegration. Nevertheless, inflammatory reactions were also reported for $\mathrm{Ti}, \mathrm{TiO}_{2}$ particles and $\mathrm{Ti}$ ions as found for $\mathrm{CoCr}$-based debris. Additionally, the presence of $\mathrm{V}$ and $\mathrm{Al}$ ions has been associated with potential mutagenic and carcinogenic response $[86,87,93]$. The development of biocompatible titanium alloys, without potentially toxic elements like $\mathrm{Al}$ or $\mathrm{V}$ and the surface modification methods have been the targets for recent research. Nowadays, TiZr and TiZrNbTa alloys are alternative materials to replace Ti6Al4V.

\section{Concluding Remarks}

The temporomandibular joint total joint replacement (TMJ TJR) involves the use of different of materials, design, and surgical techniques. TMJ TJR prostheses have clinical limitations as they only allow translational movements and therefore the mandibular movements in unilateral prostheses are performed with deflection towards the prosthetic side. The anatomical shape of the custom-made prostheses reveals a better mechanical behavior considering the distribution of stresses and mechanical stability when compared to standard prostheses. As a consequence of high loads and friction, the sliding of the bearing components of the prosthesis causes wear of the materials and, consequently, the release of metallic debris to the surrounding tissues. Metallic particles and ions released from the materials' degradation can induce inflammatory response and also the internalization through cell membranes with high risks to alter cellular metabolic functions. Inflammatory reactions induced by metallic debris can cause a series of toxic effects with mutagenic risks to the patients. The use of materials with high wear resistance and less release of toxic debris is one of the main goals of current research on TMJ TJR. Thus, TMJ TJR prostheses are still the focus of development concerning pre- and post-surgical situations, taking into account technological advancements on orthopedic prostheses (i.e., hip, knee prostheses). 
Despite the limitations, the use of TMJ TJR prostheses has increased over the years due to technological developments in materials, design, and surgical procedures.

Author Contributions: Conceptualization, J.C.M.S. and H.P.-B.; methodology, J.C.M.S. and H.P.-B.; investigation, J.C.M.S., H.P.-B., O.C. and A.R.; data curation, J.C.M.S. and H.P.-B.; writing-original draft preparation, H.P.-B., J.C.M.S.; writing-review and editing, J.C.M.S., H.P.-B., A.R. and B.H.; supervision, J.C.M.S., F.S., O.C. and A.R.; project administration, J.C.M.S.; funding acquisition, F.S. and B.H. All authors have read and agreed to the published version of the manuscript.

Funding: This study was supported by FCT-Portugal (UID/EEA/04436/2013, NORTE-01-0145FEDER-000018-HAMaBICo, POCI-01-0145-FEDER-031035_LaserMULTICER), SFRH/BPD/123769/ 2016 and CNPq-Brazil (CNPq/UNIVERSAL/421229/2018-7).

Institutional Review Board Statement: Not applicable.

Informed Consent Statement: Not applicable.

Conflicts of Interest: The authors declare no conflict of interest.

\section{References}

1. Duraccio, D.; Mussano, F.; Giulia, M. Biomaterials for dental implants: Current and future trends. J. Mater. Sci. 2015, 50, 4779-4812. [CrossRef]

2. Steinemann, S.G. Titanium-The material of choice? Periodontology 2000 1998, 17, 7-21. [CrossRef]

3. Mercuri, L.G. Temporomandibular Joint Disorder Management in Oral and Maxillofacial Surgery. J. Oral Maxillofac. Surg. 2017, 75, 927-930. [CrossRef] [PubMed]

4. Mamidi, S.K.; Klutcharch, K.; Rao, S.; Souza, J.C.M.M.; Mercuri, L.G.; Mathew, M.T. Advancements in temporomandibular joint total joint replacements (TMJR). Biomed. Eng. Lett. 2019, 9, 169-179. [CrossRef] [PubMed]

5. Mercuri, L.G. Total Joint Reconstruction-Autologous or Alloplastic. Oral Maxillofac. Surg. Clin. N. Am. 2006, 18, 399-410. [CrossRef] [PubMed]

6. Onoriobe, U.; Miloro, M.; Sukotjo, C.; Mercuri, L.G.; Lotesto, A.; Eke, R. How Many Temporomandibular Joint Total Joint Alloplastic Implants Will Be Placed in the United States in 2030? J. Oral Maxillofac. Surg. 2016, 74, 1531-1538. [CrossRef] [PubMed]

7. Kerwell, S.; Alfaro, M.; Pourzal, R.; Lundberg, H.J.; Liao, Y.; Sukotjo, C.; Mercuri, L.G.; Mathew, M.T. Examination of failed retrieved temporomandibular joint (TMJ) implants. Acta Biomater. 2016, 32, 324-335. [CrossRef]

8. Gakhal, M.K.; Gupta, B.; Sidebottom, A.J. Analysis of outcomes after revision replacement of failed total temporomandibular joint prostheses. Br. J. Oral Maxillofac. Surg. 2020, 58, 220-224. [CrossRef]

9. Rodrigues, Y.L.; Mathew, M.T.; Mercuri, L.G.; da Silva, J.S.P.; Henriques, B.; Souza, J.C.M. Biomechanical Simulation of Temporomandibular Joint Replacement (TMJR) Devices: A Scoping Review of the Finite Element Method; Churchill Livingstone: London, UK, 2018; Volume 47, pp. 1032-1042.

10. De Meurechy, N.; Mommaerts, M.Y. Alloplastic temporomandibular joint replacement systems: A systematic review of their history. Int. J. Oral Maxillofac. Surg. 2018, 47, 743-754. [CrossRef]

11. Wolford, L.; Movahed, R.; Teschke, M.; Fimmers, R.; Havard, D.; Schneiderman, E. Temporomandibular joint ankylosis can be successfully treated with TMJ concepts patient-fitted total joint prosthesis and autogenous fat grafts. J. Oral Maxillofac. Surg. 2016, 74, 1215-1227. [CrossRef]

12. Sadoghi, P.; Liebensteiner, M.; Agreiter, M.; Leithner, A.; Böhler, N.; Labek, G. Revision surgery after total joint arthroplasty: A complication-based analysis using worldwide arthroplasty registers. J. Arthroplast. 2013, 28, 1329-1332. [CrossRef]

13. Wolford, L.M.; Mercuri, L.G.; Schneiderman, E.D.; Movahed, R.; Allen, W. Twenty-year follow-up study on a patient-fitted temporomandibular joint prosthesis: The Techmedica/TMJ Concepts device. J. Oral Maxillofac. Surg. 2015, 73, 952-960. [CrossRef]

14. Germain, M.A.; Hatton, A.; Williams, S.; Matthews, J.B.; Stone, M.H.; Fisher, J.; Ingham, E. Comparison of the cytotoxicity of clinically relevant cobalt-chromium and alumina ceramic wear particles in vitro. Biomaterials 2003, 24, 469-479. [CrossRef]

15. Papageorgiou, I.; Brown, C.; Schins, R.; Singh, S.; Newson, R.; Davis, S.; Fisher, J.; Ingham, E.; Case, C.P. The effect of nano- and micron-sized particles of cobalt-chromium alloy on human fibroblasts in vitro. Biomaterials 2007, 28, 2946-2958. [CrossRef] [PubMed]

16. De Moura Silva, A.; de Figueiredo, V.M.G.; do Prado, R.F.; de Fatima Santanta-Melo, G.; Del Valle El Abras Ankha, M.; de Vasconcellos, L.M.R.; da Silva Sobrinho, A.S.; Borges, A.L.S.; Nogueira, L., Jr. Diamond-like carbon films over reconstructive TMJ prosthetic materials: Effects in the cytotoxicity, chemical and mechanical properties. J. Oral Biol. Craniofacial Res. 2019, 9, 201-207. [CrossRef]

17. Akbar, M.; Fraser, A.R.; Graham, G.J.; Brewer, J.M.; Grant, M.H. Acute inflammatory response to cobalt chromium orthopaedic wear debris in a rodent air-pouch model. J. R. Soc. Interface 2012, 9, 2109-2119. [CrossRef] [PubMed]

18. Drynda, A.; Ren, Q.; Buchhorn, G.H.; Lohmann, C.H. The induction of CXCR4 expression in human osteoblast-like cells (MG63) by CoCr particles is regulated by the PLC-DAG-PKC pathway. J. Biomed. Mater. Res. Part B Appl. Biomater. 2017, 105, 2326-2332. [CrossRef] [PubMed] 
19. Fu, S.; Meng, H.; Freer, F.; Kwon, J.; Shelton, J.C.; Knight, M.M. Sub-toxic levels of $\mathrm{Co}^{2+}$ are anti-inflammatory and protect cartilage from degradation caused by IL-1ß. Clin. Biomech. 2020. [CrossRef]

20. Li, D.; Wang, H.; Li, Z.; Wang, C.; Xiao, F.; Gao, Y.; Zhang, X.; Wang, P.; Peng, J.; Cai, G.; et al. The inhibition of RANKL expression in fibroblasts attenuate $\mathrm{CoCr}$ particles induced aseptic prosthesis loosening via the MyD88-independent TLR signaling pathway. Biochem. Biophys. Res. Commun. 2018, 503, 1115-1122. [CrossRef]

21. Lee, S.-H.; Ryu, D.-J.; Kim, H.-S.; Kim, H.-G.; Huh, J.-K. Alloplastic total temporomandibular joint replacement using stock prosthesis: A one-year follow-up report of two cases. J. Korean Assoc. Oral Maxillofac. Surg. 2013, 39, 297. [CrossRef]

22. Abramowicz, S.; Barbick, M.; Rose, S.P.; Dolwick, M.F. Adaptability of stock TMJ prosthesis to joints that were previously treated with custom joint prosthesis. Int. J. Oral Maxillofac. Surg. 2012, 41, 518-520. [CrossRef]

23. Mercuri, L.G. The role of custom-made prosthesis for temporomandibular joint replacement. Rev. Española Cirugía Oral Maxilofac. 2013, 35, 1-10. [CrossRef]

24. Dhanda, J.; Cooper, C.; Ellis, D.; Speculand, B. Technique of temporomandibular joint replacement using a patient-specific reconstruction system in the edentulous patient. Br. J. Oral Maxillofac. Surg. 2011, 49, 618-622. [CrossRef] [PubMed]

25. Ryu, J.; Cho, J.; Kim, H.M. Bilateral temporomandibular joint replacement using computer-assisted surgical simulation and three-dimensional printing. J. Craniofac. Surg. 2016, 27, e450-e452. [CrossRef] [PubMed]

26. Kakuguchi, W.; Yamaguchi, H.O.; Inoue, N.; Totsuka, Y. Postoperative management of arthroplasty by using unique splints in almost edentulous patient. Br. J. Oral Maxillofac. Surg. 2012, 50, 270-271. [CrossRef] [PubMed]

27. Haq, J.; Patel, N.; Weimer, K.; Matthews, N.S. Single stage treatment of ankylosis of the temporomandibular joint using patient-specific total joint replacement and virtual surgical planning. Br. J. Oral Maxillofac. Surg. 2014, 52, 350-355. [CrossRef]

28. Guarda-Nardini, L.; Manfredini, D.; Ferronato, G. Temporomandibular joint total replacement prosthesis: Current knowledge and considerations for the future. Int. J. Oral Maxillofac. Surg. 2008, 37, 103-110. [CrossRef]

29. Van Loon, J.P.; Verkerke, G.J.; De Vries, M.P.; De Bont, L.G.M. Design and wear testing of a temporomandibular joint prosthesis articulation. J. Dent. Res. 2000, 79, 715-721. [CrossRef]

30. Mercuri, L.G.; Miloro, M.; Skipor, A.K.; Bijukumar, D.; Sukotjo, C.; Mathew, M.T. Serum Metal Levels in Maxillofacial Reconstructive Surgery Patients: A Pilot Study. J. Oral Maxillofac. Surg. 2018, 76, 2074-2080. [CrossRef]

31. Mercuri, L.G.; Mathew, M.T.; Kerwell, S.; Lundberg, H.; Sukotjo, C. Temporomandibular Joint Replacement Device Research Wear and Corrosion Technology Transfer from Orthopedics. J. Bio Tribo Corros. 2015, 1. [CrossRef]

32. Gonzalez-Perez, L.M.; Gonzalez-Perez-Somarriba, B.; Centeno, G.; Vallellano, C.; Montes-Carmona, J.F.; Torres-Carranza, E.; Ambrosiani-Fernandez, J.; Infante-Cossio, P. Prospective study of five-year outcomes and postoperative complications after total temporomandibular joint replacement with two stock prosthetic systems. Br. J. Oral Maxillofac. Surg. 2019. [CrossRef] [PubMed]

33. De Meurechy, N.K.G.; Zaror, C.E.; Mommaerts, M.Y. Total Temporomandibular Joint Replacement: Stick to Stock or Optimization by Customization? Craniomaxillofac. Trauma Reconstr. 2020, 13, 59-70. [CrossRef] [PubMed]

34. Altaf, H.; Revell, P.A. Evidence for active antigen presentation by monocyte/macrophages in response to stimulation with particles: The expression of NFkB transcription factors and costimulatory molecules. Inflammopharmacology 2013, 21, 279-290. [CrossRef] [PubMed]

35. De Meurechy, N.; Braem, A.; Mommaerts, M.Y. Biomaterials in temporomandibular joint replacement: Current status and future perspectives-a narrative review. Int. J. Oral Maxillofac. Surg. 2018, 47, 518-533. [CrossRef] [PubMed]

36. Driemel, O.; Braun, S.; Müller-Richter, U.D.A.; Behr, M.; Reichert, T.E.; Kunkel, M.; Reich, R. Historical development of alloplastic temporomandibular joint replacement after 1945 and state of the art. Int. J. Oral Maxillofac. Surg. 2009, 38, 909-920. [CrossRef]

37. Zou, L.; Zhang, L.; He, D.; Yang, C.; Zhao, J.; Ellis, E. Clinical and Radiologic Follow-Up of Zimmer Biomet Stock Total Temporomandibular Joint Replacement After Surgical Modifications. J. Oral Maxillofac. Surg. 2018, 76, 2518-2524. [CrossRef] [PubMed]

38. Ramos, A.; Mesnard, M. Christensen vs Biomet Microfixation alloplastic TMJ implant: Are there improvements? A numerical study. J. Cranio-Maxillofac. Surg. 2015, 43, 1398-1403. [CrossRef]

39. Gerbino, G.; Zavattero, E.; Bosco, G.; Berrone, S.; Ramieri, G. Temporomandibular joint reconstruction with stock and custommade devices: Indications and results of a 14-year experience. J. Cranio-Maxillofac. Surg. 2017, 45, 1710-1715. [CrossRef]

40. Giannakopoulos, H.E.; Sinn, D.P.; Quinn, P.D. Biomet microfixation temporomandibular joint replacement system: A 3-year follow-up study of patients treated during 1995 to 2005. J. Oral Maxillofac. Surg. 2012, 70, 787-794. [CrossRef]

41. Kanatsios, S.; Breik, O.; Dimitroulis, G. Biomet stock temporomandibular joint prosthesis: Long-term outcomes of the use of titanium condyles secured with four or five condylar fixation screws. J. Cranio-Maxillofac. Surg. 2018, 46, 1697-1702. [CrossRef]

42. Baena, J.; Wu, J.; Peng, Z. Wear Performance of UHMWPE and Reinforced UHMWPE Composites in Arthroplasty Applications: A Review. Lubricants 2015, 3, 413-436. [CrossRef]

43. Elledge, R.; Mercuri, L.G.; Attard, A.; Green, J.; Speculand, B. Review of emerging temporomandibular joint total joint replacement systems. Br. J. Oral Maxillofac. Surg. 2019, 57, 722-728. [CrossRef]

44. Ferreira, F.M.; Cunali, R.S.; Bonotto, D.; de Farias, A.C.; Cunali, P.A. Total temporomandibular joint alloplastic reconstruction. Rev. Dor 2014, 15. [CrossRef]

45. Mathew, M.T.; Kerwell, S.; Lundberg, H.J.; Sukotjo, C.; Mercuri, L.G. Tribocorrosion and oral and maxillofacial surgical devices. Br. J. Oral Maxillofac. Surg. 2014, 52, 396-400. [CrossRef]

46. Johnson, N.R.; Roberts, M.J.; Doi, S.A.; Batstone, M.D. Total temporomandibular joint replacement prostheses: A systematic review and bias-adjusted meta-analysis. Int. J. Oral Maxillofac. Surg. 2017, 46, 86-92. [CrossRef] [PubMed] 
47. Bai, G.; Yang, C.; He, D.; Zhang, X.; Abdelrehem, A. Application of fossa bone graft to stabilize stock total joint prosthesis in temporomandibular joint surgery. J. Cranio-Maxillofac. Surg. 2015, 43, 1392-1397. [CrossRef] [PubMed]

48. Hu, Y.; Zhang, L.; He, D.; Yang, C.; Chen, M.; Zhang, S.; Li, H.; Ellis, E., III. Simultaneous treatment of temporomandibular joint ankylosis with severe mandibular deficiency by standard TMJ prosthesis. Sci. Rep. 2017, 7, 45271. [CrossRef]

49. Rhee, S.-H.; Baek, S.-H.; Park, S.-H.; Kim, J.-C.; Jeong, C.-G.; Choi, J.-Y. Total joint reconstruction using computer-assisted surgery with stock prostheses for a patient with bilateral TMJ ankylosis. Maxillofac. Plast. Reconstr. Surg. 2019, 41. [CrossRef]

50. Moreira, C.V.A.; Serra, A.V.P.; Silva, L.O.R.; Fernandes, A.C.F.; de Azevedo, R.A. Total bilateral TMJ reconstruction for pain and dysfunction: Case report. Int. J. Surg. Case Rep. 2018, 42, 138-144. [CrossRef] [PubMed]

51. Westermark, A.; Leiggener, C.; Aagaard, E.; Lindskog, S. Histological findings in soft tissues around temporomandibular joint prostheses after up to eight years of function. Int. J. Oral Maxillofac. Surg. 2011, 40, 18-25. [CrossRef]

52. Siegmund, B.J.; Winter, K.; Meyer-Marcotty, P.; Rustemeyer, J. Reconstruction of the temporomandibular joint: A comparison between prefabricated and customized alloplastic prosthetic total joint systems. Int. J. Oral Maxillofac. Surg. 2019, 48, 1066-1071. [CrossRef]

53. Brown, Z.L.; Sarrami, S.; Perez, D.E. Will they fit? Determinants of the adaptability of stock TMJ prostheses where custom TMJ prostheses were utilized. Int. J. Oral Maxillofac. Surg. 2020. [CrossRef] [PubMed]

54. Elledge, R.; Mercuri, L.G.; Speculand, B. Extended total temporomandibular joint replacements: A classification system. Br. J. Oral Maxillofac. Surg. 2018, 56, 578-581. [CrossRef] [PubMed]

55. Mercuri, L.G. Alloplastic temporomandibular joint replacement: Rationale for the use of custom devices. Int. J. Oral Maxillofac. Surg. 2012, 41, 1033-1040. [CrossRef] [PubMed]

56. Ettinger, K.S.; Arce, K.; Fillmore, W.J.; Van Ess, J.M.; Yetzer, J.G.; Viozzi, C.F. Does the Amount of Screw Fixation Utilized for the Condylar Component of the TMJ Concepts Total Temporomandibular Joint Reconstruction Predispose to Hardware Loss or Postoperative Complications? J. Oral Maxillofac. Surg. 2016, 74, 1741-1750. [CrossRef] [PubMed]

57. Farzad, P. Reconstruction of nongrowing hemifacial microsomia patient with custom-made unilateral temporomandibular joint total joint prosthesis and orthognathic surgery. J. Oral Biol. Craniofac. Res. 2017, 7, 62-66. [CrossRef]

58. Gruber, E.A.; McCullough, J.; Sidebottom, A.J. Medium-term outcomes and complications after total replacement of the temporomandibular joint. Prospective outcome analysis after 3 and 5 years. Br. J. Oral Maxillofac. Surg. 2015, 53, 412-415. [CrossRef]

59. Park, J.-H.; Jo, E.; Cho, H.; Kim, H.J. Temporomandibular joint reconstruction with alloplastic prosthesis: The outcomes of four cases. Maxillofac. Plast. Reconstr. Surg. 2017, 39. [CrossRef]

60. Van Loon, J.P.; de Bont, L.G.M.; Boering, G. Evaluation of temporomandibular joint prostheses. Review of the literature from 1946 to 1994 and implications for future prosthesis designs. J. Oral Maxillofac. Surg. 1995, 53, 984-996. [CrossRef]

61. Ramos, A.; Mesnard, M. A new condyle implant design concept for an alloplastic temporomandibular joint in bone resorption cases. J. Cranio-Maxillofac. Surg. 2016, 44, 1670-1677. [CrossRef]

62. Mesnard, M.; Ramos, A. Experimental and numerical predictions of Biomet ${ }^{\circledR}$ alloplastic implant in a cadaveric mandibular ramus. J. Cranio-Maxillofac. Surg. 2016, 44, 608-615. [CrossRef]

63. Ramos, A.; Mesnard, M.; Relvas, C.; Completo, A.; Simões, J.A. Theoretical assessment of an intramedullary condylar component versus screw fixation for the condylar component of a hemiarthroplasty alloplastic TMJ replacement system. J. Cranio-Maxillofac. Surg. 2014, 42, 169-174. [CrossRef]

64. Ramos, A.; Mesnard, M. Comparison of load transfers in TMJ replacement using a standard and a custom-made temporal component. J. Cranio-Maxillofac. Surg. 2014, 42, 1766-1772. [CrossRef]

65. Ramos, A.; Completo, A.; Relvas, C.; Mesnard, M.; Simões, J.A. Straight, semi-anatomic and anatomic TMJ implants: The influence of condylar geometry and bone fixation screws. J. Cranio-Maxillofac. Surg. 2011, 39, 343-350. [CrossRef]

66. Sinno, H.; Tahiri, Y.; Gilardino, M.; Bobyn, D. Engineering alloplastic temporomandibular joint replacements. McGill J. Med. 2011, $13,63$.

67. Souza, J.C.M.; Henriques, M.; Teughels, W.; Ponthiaux, P.; Celis, J.-P.; Rocha, L.A. Wear and Corrosion Interactions on Titanium in Oral Environment: Literature Review. J. Bio-Tribo-Corros. 2015, 1, 13. [CrossRef]

68. Buciumeanu, M.; Bagheri, A.; Souza, J.C.M.; Silva, F.S.; Henriques, B. Tribocorrosion behavior of hot pressed CoCrMo alloys in artificial saliva. Tribol. Int. 2016. [CrossRef]

69. Souza, J.C.M.; Barbosa, S.L.; Ariza, E.; Celis, J.P.; Rocha, L.A. Simultaneous degradation by corrosion and wear of titanium in artificial saliva containing fluorides. Wear 2012, 292-293, 82-88. [CrossRef]

70. Alves, S.A.; Beline, T.; Barão, V.A.R.; Sukotjo, C.; Mathew, M.T.; Rocha, L.A.; Celis, J.-P.; Souza, J.C.M. Chapter 3-Degradation of titanium-based implants. In Advanced Nanomaterials; Souza, J.C.M., Hotza, D., Henriques, B., Boccaccini, A.R., Eds.; Elsevier: Amsterdam, The Netherlands, 2018; pp. 41-62. ISBN 978-0-12-814621-7. [CrossRef]

71. Landolt, D. Corrosion and Surface Chemistry of Metals, 1st ed.; EPFL Press: Lausanne, Switzerland, 2007; ISBN 978-2-940222-11-7.

72. Barril, S.; Debaud, N.; Mischler, S.; Landolt, D. A tribo-electrochemical apparatus for in vitro investigation of fretting-corrosion of metallic implant materials. Wear 2002, 252, 744-754. [CrossRef]

73. Souza, J.C.M.; Henriques, M.; Oliveira, R.; Teughels, W.; Celis, J.-P.; Rocha, L.A. Biofilms inducing ultra-low friction on titanium. J. Dent. Res. 2010, 89, 1470-1475. [CrossRef] [PubMed] 
74. Souza, J.C.M.; Barbosa, S.L.; Ariza, E.A.; Henriques, M.; Teughels, W.; Ponthiaux, P.; Celis, J.P.; Rocha, L.A. How do titanium and Ti6Al4V corrode in fluoridated medium as found in the oral cavity? An in vitro study. Mater. Sci. Eng. C 2015, 47, 384-393. [CrossRef] [PubMed]

75. Souza, J.C.M.; Henriques, M.; Oliveira, R.; Teughels, W.; Celis, J.-P.; Rocha, L.A. Do oral biofilms influence the wear and corrosion behavior of titanium? Biofouling 2010, 26, 471-478. [CrossRef] [PubMed]

76. Doni, Z.; Alves, A.C.; Toptan, F.; Gomes, J.R.; Ramalho, A.; Buciumeanu, M.; Palaghian, L.; Silva, F.S. Dry sliding and tribocorrosion behaviour of hot pressed CoCrMo biomedical alloy as compared with the cast CoCrMo and Ti6Al4V alloys. Mater. Des. 2013, 52, 47-57. [CrossRef]

77. Alves, A.C.; Oliveira, F.; Wenger, F.; Ponthiaux, P.; Celis, J.-P.; Rocha, L.A. Tribocorrosion behaviour of anodic treated titanium surfaces intended for dental implants. J. Phys. D Appl. Phys. 2013, 46, 404001. [CrossRef]

78. Teeter, M.G.; MacLean, C.J.; Somerville, L.E.; Howard, J.L.; McCalden, R.W.; Lanting, B.A.; Vasarhelyi, E.M. Wear performance of cobalt chromium, ceramic, and oxidized zirconium on highly crosslinked polyethylene at mid-term follow-up. J. Orthop. 2018, 15, 620-623. [CrossRef]

79. Patil, N.A.; Njuguna, J.; Kandasubramanian, B. UHMWPE for biomedical applications: Performance and functionalization. Eur. Polym. J. 2020, 125, 109529. [CrossRef]

80. Lei, P.; Dai, Z.; Zhang, Y.S.; Liu, H.; Niu, W.; Li, K.; Wang, L.; Hu, Y.; Xie, J. Macrophage inhibits the osteogenesis of fibroblasts in ultrahigh molecular weight polyethylene (UHMWPE) wear particle-induced osteolysis. J. Orthop. Surg. Res. 2019, 14, 80. [CrossRef]

81. McCalden, R.W.; MacDonald, S.J.; Rorabeck, C.H.; Bourne, R.B.; Chess, D.G.; Charron, K.D. Wear rate of highly cross-linked polyethylene in total hip arthroplasty. A randomized controlled trial. J. Bone Jt. Surg. Am. 2009, 91, 773-782. [CrossRef]

82. Hamlekhan, A.; Butt, A.; Patel, S.; Royhman, D.; Takoudis, C.; Sukotjo, C.; Yuan, J.; Jursich, G.; Mathew, M.T.; Hendrickson, W.; et al. Fabrication of Anti-Aging $\mathrm{TiO}_{2}$ Nanotubes on Biomedical Ti Alloys. PLoS ONE 2014, 9, e96213. [CrossRef]

83. Mercuri, L.G.; Urban, R.M.; Hall, D.J.; Mathew, M.T. Adverse Local Tissue Responses to Failed Temporomandibular Joint Implants. J. Oral Maxillofac. Surg. 2017, 75, 2076-2084. [CrossRef]

84. Noronha Oliveira, M.; Schunemann, W.V.H.; Mathew, M.T.; Henriques, B.; Magini, R.S.; Teughels, W.; Souza, J.C.M. Can degradation products released from dental implants affect peri-implant tissues? J. Periodontal. Res. 2018, 53, 1-11. [CrossRef]

85. Reddy, A.; Caicedo, M.S.; Samelko, L.; Jacobs, J.J.; Hallab, N.J. Implant debris particle size affects serum protein adsorption which may contribute to particle size-based bioreactivity differences. J. Long-Term Eff. Med. Implants 2014, 24, 77-88. [CrossRef]

86. Bijukumar, D.R.; Segu, A.; Souza, J.C.M.; Li, X.J.; Barba, M.; Mercuri, L.G.; Jacobs, J.; Mathew, M.T. Systemic and local toxicity of metal debris released from hip prostheses: A review of experimental approaches. Nanomed. Nanotechnol. Biol. Med. 2018, 14, 951-963. [CrossRef] [PubMed]

87. Apaza-Bedoya, K.; Tarce, M.; Benfatti, C.A.M.; Henriques, B.; Mathew, M.T.; Teughels, W.; Souza, J.C.M. Synergistic interactions between corrosion and wear at titanium-based dental implant connections: A scoping review. J. Periodontal. Res. 2017, 52, 946-954. [CrossRef] [PubMed]

88. Zaveri, T.D.; Dolgova, N.V.; Lewis, J.S.; Hamaker, K.; Clare-Salzler, M.J.; Keselowsky, B.G. Macrophage integrins modulate response to ultra-high molecular weight polyethylene particles and direct particle-induced osteolysis. Biomaterials 2017, 115, 128-140. [CrossRef] [PubMed]

89. Liu, A.; Richards, L.; Bladen, C.L.; Ingham, E.; Fisher, J.; Tipper, J.L. The biological response to nanometre-sized polymer particles. Acta Biomater. 2015, 23, 38-51. [CrossRef] [PubMed]

90. Ribeiro, A.R.; Gemini-Piperni, S.; Travassos, R.; Lemgruber, L.; Silva, R.C.; Rossi, A.L.; Farina, M.; Anselme, K.; Shokuhfar, T.; Shahbazian-Yassar, R.; et al. Trojan-Like Internalization of Anatase Titanium Dioxide Nanoparticles by Human Osteoblast Cells. Sci. Rep. 2016, 6, 23615. [CrossRef]

91. Royhman, D.; Radhakrishnan, R.; Yuan, J.C.-C.; Mathew, M.T.; Mercuri, L.G.; Sukotjo, C. An electrochemical investigation of TMJ implant metal alloys in an artificial joint fluid environment: The influence of $\mathrm{pH}$ variation. J. Craniomaxillofac. Surg. 2014, 42, 1052-1061. [CrossRef] [PubMed]

92. Pourzal, R.; Catelas, I.; Theissmann, R.; Kaddick, C.; Fischer, A. Characterization of wear particles generated from CoCrMo alloy under sliding wear conditions. Wear 2011, 271, 1658-1666. [CrossRef]

93. Messous, R.; Henriques, B.; Bousbaa, H.; Silva, F.S.; Teughels, W.; Souza, J.C.M. Cytotoxic effects of submicron- and nano-scale titanium debris released from dental implants: An integrative review. Clin. Oral Investig. 2021. [CrossRef]

94. Catelas, I.; Petit, A.; Vali, H.; Fragiskatos, C.; Meilleur, R.; Zukor, D.J.; Antoniou, J.; Huk, O.L. Quantitative analysis of macrophage apoptosis vs. necrosis induced by cobalt and chromium ions in vitro. Biomaterials 2005, 26, 2441-2453. [CrossRef] [PubMed]

95. Urban, R.M.; Jacobs, J.J.; Tomlinson, M.J.; Gavrilovic, J.; Black, J.; Peoc'h, M. Dissemination of wear particles to the liver, spleen, and abdominal lymph nodes of patients with hip or knee replacement. J. Bone Jt. Surg. 2000, 82, 457. [CrossRef] [PubMed]

96. Jakobsen, S.S.; Danscher, G.; Stoltenberg, M.; Larsen, A.; Bruun, J.M.; Mygind, T.; Kemp, K.; Soballe, K. Cobalt-chromiummolybdenum alloy causes metal accumulation and metallothionein up-regulation in rat liver and kidney. Basic Clin. Pharmacol. Toxicol. 2007, 101, 441-446. [CrossRef] [PubMed] 